\title{
Teaching the Unteachable or Why Too Much Good Is Bad. Religious Education in Catholic Schools Today
}

\author{
Didier Pollefeyt
}

Citation: Pollefeyt, Didier. 2021. Teaching the Unteachable or Why Too Much Good Is Bad. Religious Education in Catholic Schools Today. Religions 12: 810. https://doi.org/ $10.3390 /$ rel12100810

Academic Editor: Eamonn Conway

Received: 24 August 2021

Accepted: 15 September 2021

Published: 27 September 2021

Publisher's Note: MDPI stays neutral with regard to jurisdictional claims in published maps and institutional affiliations.

Copyright: (C) 2021 by the author. Licensee MDPI, Basel, Switzerland. This article is an open access article distributed under the terms and conditions of the Creative Commons Attribution (CC BY) license (https:/ / creativecommons.org/licenses/by/ $4.0 /)$.
Faculty of Theology and Religious Studies, KU Leuven, 3000 Leuven, Belgium; Didier.Pollefeyt@kuleuven.be
Abstract: This article deals with the strong disaffiliation of Church and Catholic faith we see in the Western world, especially when students go from primary to secondary school, and when leaving the Catholic educational system. Based on empirical data, the hypothesis is formulated that Catholic schools use a pedagogy that is too much concerned with positive theology and psychology, an approach that does not stand the test when life shows its complexities and vulnerabilities. The article presents theologies and pedagogies of responsibility and vulnerability as a complimentary approach, rooted in the Catholic tradition, as a possible way to form more resilient believers and citizens for the future.

Keywords: religious education; Catholic schools; school identity

"If you comprehend, it is not God" (Augustine of Hippo, Sermon 15,16)

"Our heart is restless until it rests in You" (Augustine of Hippo, Confessions, 1.1.1)

\section{Introduction}

In the past fifteen years, I have had the privilege to research extensively the identity of Catholic schools in Western Europe, in the United States, and particularly also in Australia. Our research group on Enhancing Catholic School Identity (ECSI) has been gathering quantitative and qualitative data from over half a million subjects from more than 1500 Catholic educational institutions around the world: students, teachers, principals, parents, priests, and members of school boards and diocesan offices for Catholic education. We enjoyed the hospitality of many Catholic schools as we engaged with our survey data in order to appraise and to align it with the concrete reality of school life.

Our main goal is not just to assess Catholic school identity, but expressly to enhance the mission of the Catholic school "as a place of integral education of the human person through a clear educational project of which Christ is the foundation" (Congregation for Catholic Education 1997). We do this from within an explicit theological framework that views the Catholic school as a hospitable educational community that recontextualises the Catholic faith from a post-critical belief stance in dialogue with the actual context. Within this theological framework, we evaluate how Catholic schools all around the world respond to the universal tendencies of detraditionalisation, secularisation, pluralisation, and globalisation.

In this presentation, we use the ECSI data of Catholic schools in one large Catholic diocese in Australia as a paradigmatic starting point to formulate one of the main challenges we discover today in Catholic schools. Next, we present the analysis we make of this challenge, and the perspective we see for the future to strengthen Catholic education in its mission. Moreover, this analysis is not limited to the area of education: it challenges the way the Catholic Church as such communicates itself in the contemporary world.

\section{The Challenge: A Strong Disaffiliation of Church and Catholic Faith}

The vocation of Catholic schools is to offer a formation that invites students to develop a life-long and resilient faith inspired by the Catholic tradition and open to the world of 
today. Such a belief distances itself from any form of fundamentalism and intolerance. It can deal with the critical dialogue between science and religion, and it is aware of the diversity of religions and world views in our contemporary context. It is 'post-critical' because it does not self-destruct when literal understandings of faith become unsustainable, when reason asks difficult questions, or when it is confronted by other world views. In other words, it is a belief that overcomes literal belief, external critique, and relativism. It is characterised by a desire to encounter the Divine Reality through Scripture, the tradition, the sacraments, and the Catholic faith community-even though this God also always remains the 'Other' who is imperceptible, intangible, and always greater than human attempts at comprehension (Deus semper maior).

In the post-critical belief scale, we have indicated this 'ideal' well-developed faith position with a yellow marker, the so-called 'golden dot'. It denotes a belief in a personal God through strong mediations that create a living relationship with the Divine (Figure 1). The post-critical belief scale (or PCB-scale) helps us to see where members of the school stand concerning the four different 'cognitive belief styles'.

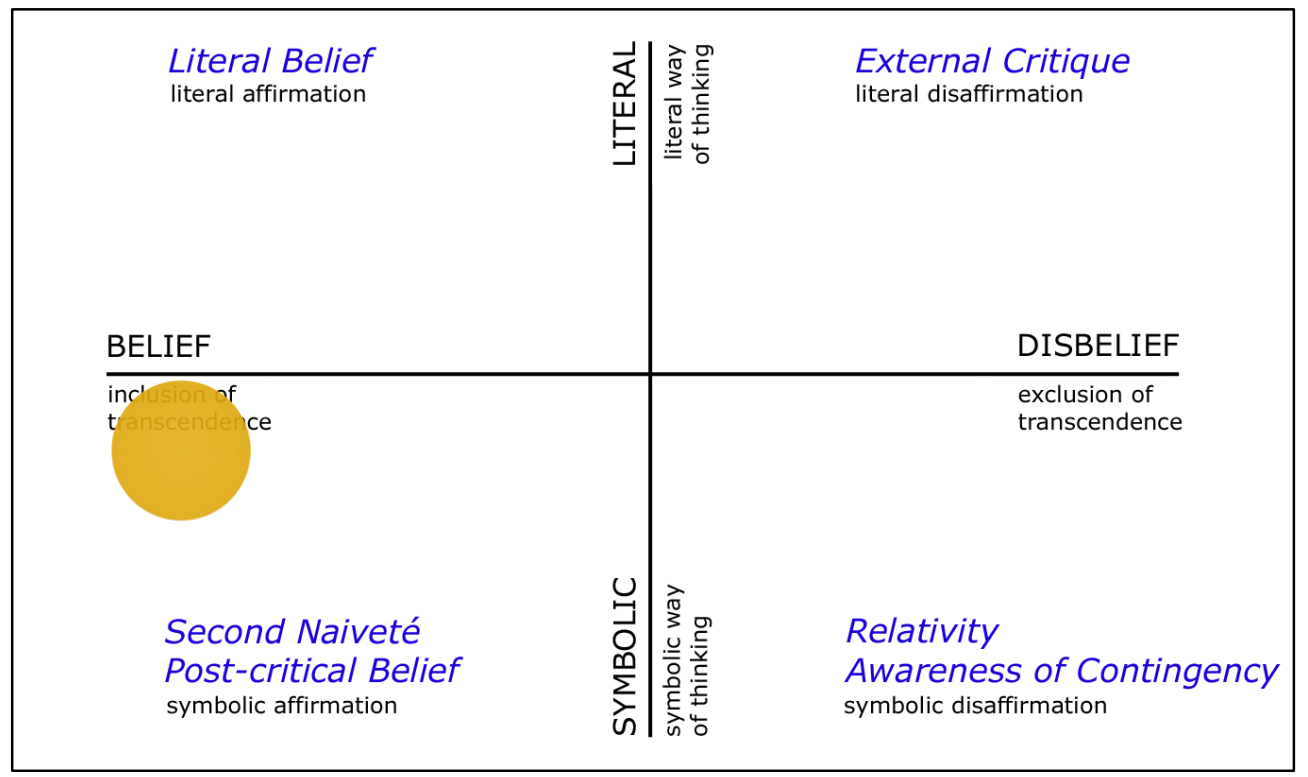

Figure 1. Framework of the post-critical belief scale with 'golden dot'.

Figure 2 shows the cognitive belief styles of more than 15,000 students (year 5-6, year 7-8, year 9-10, year 11-12) and almost 7000 adults (parents, teachers, school leadership) in Catholic schools in an Australian diocese in the period between 2012 and 2019 (eight years). If we isolate the results of the adult groups in this graph (the dark blue, green, and brown bars), we discover that their cognitive belief styles are close to the theological normative point or 'golden dot' in Figure 1. Parents, teachers, and school leadership reject literal belief styles, both literal belief and literal disbelief. Instead, they promote a dominant post-critical belief that is at the same time aware and appreciative of other beliefs and world views. The school leadership best approaches the normative point (5.4), followed by the teachers (5.3) and the parents (5.1). From a theological-normative perspective, we could say that Catholic schools (in this diocese) are in good hands. 


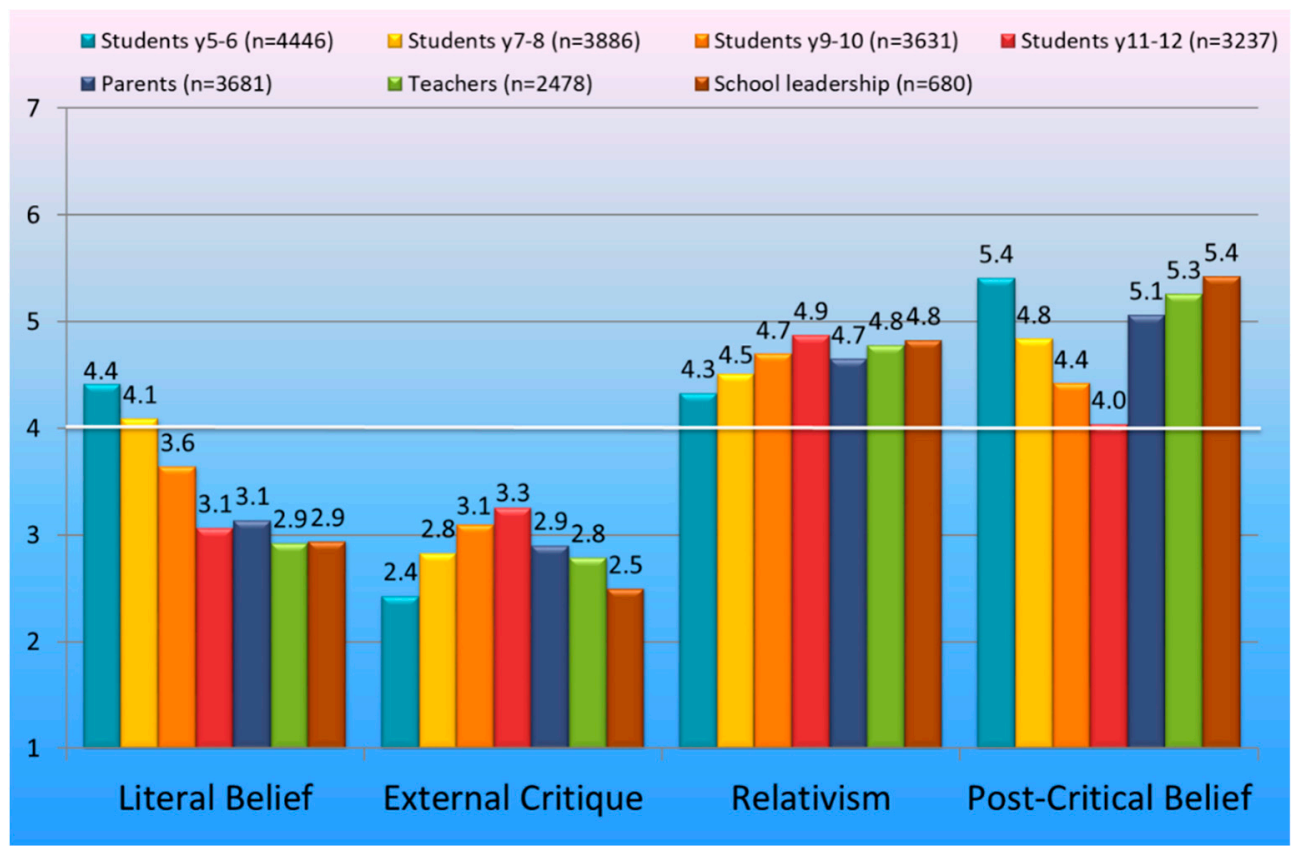

Figure 2. PCB-scale results among all respondent groups.

However, if we isolate the data of the students, we see another pattern. Primary school children (in light blue) start with a remarkably firm literal belief (4.4), but as they grow older their approval of literal belief turns into rejection. As such, this is not overly remarkable as teenagers step-by-step approach the low level of literal belief present among adults. What is more striking, however, is the clear simultaneous rise of relativism and external critique, and notably the downward drop of post-critical belief (from 5.4 to 4.0). When we isolate the students in years 11-12 in secondary college, we see how relativism (4.7) has become the dominant way of dealing with belief at the expense of post-critical belief (4.0). In years 11-12, external critique is also becoming stronger (3.3) than literal belief (3.1).

Overall, the challenge could be formulated as follows. Catholic education induces high levels of literal belief in children but does not create a transformation from literal belief into post-critical belief as the students grow older. Instead, Catholic schools are confronted with a steady increase of the two unbelieving coping styles, namely relativism and even external critique. In other words, when students leave the Catholic school system, most of them have completely rejected literal belief in any form. They even started hesitating about post-critical belief (4.0), and they adopted the general cultural pattern of relativism (4.9), taken over from their social environment, including a critical, rejecting undertone towards religion (3.3). We summarise this drastic shift over twelve years of Catholic education in the following scheme (Figure 3). To be clear: this shift is not typical just for this particular diocese in Australia, but we see disaffiliation happening in all parts of the Western world, in different degrees and variations 


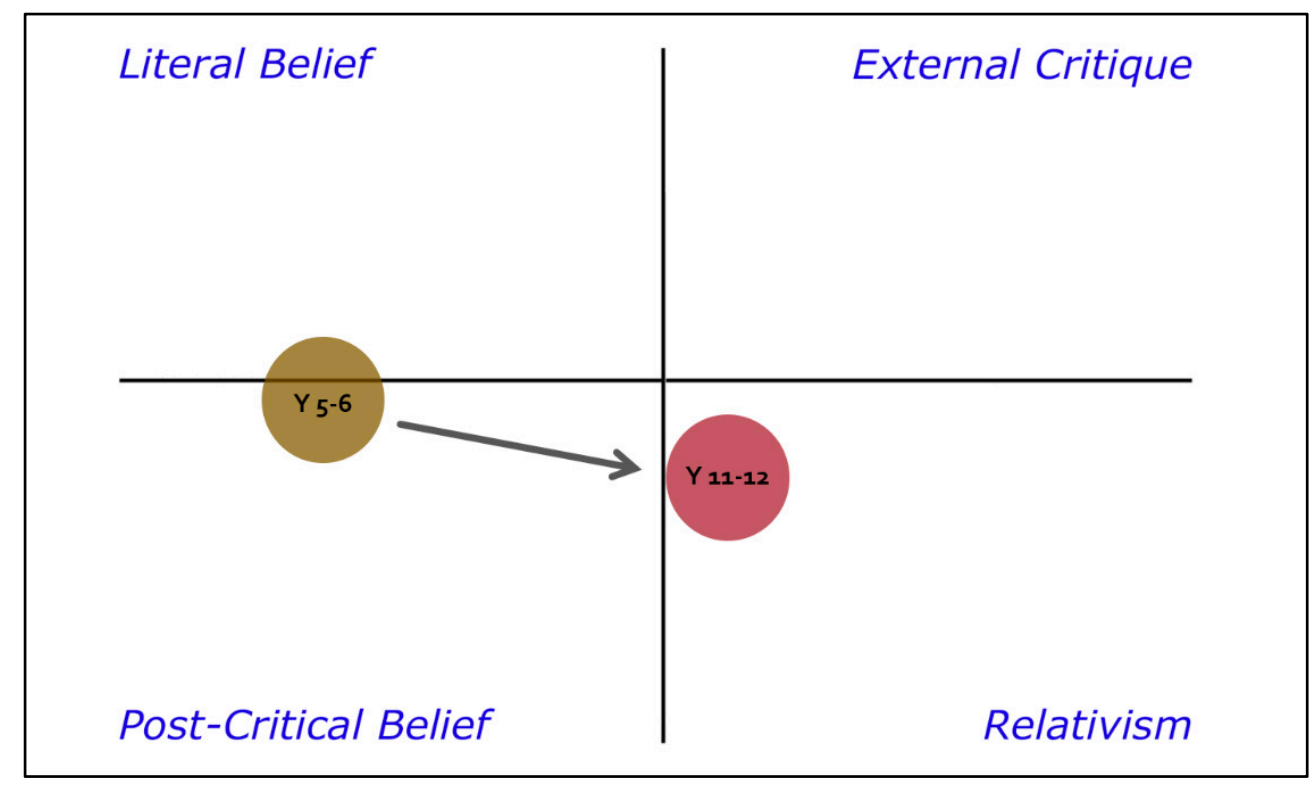

Figure 3. Evolution of students as they transition from primary to secondary education.

\section{The Analysis of the Problem}

How to understand these data and underlying developments? A first explanation that comes to mind is based on traditional models of developmental psychology, such as the one created by James W. Fowler (1940-2015). Based on their limited cognitive and moral capacities, children would simply be incapable of post-critical belief: they can think and believe only literally. Such a view that considers children as incapable, deficient, and 'not yet adults' who are only receptive to reduced and simplified notions of religiosity, is strongly criticised in contemporary children's studies. Moreover, this approach does not explain why older students, at the age when they can distinguish literal from post-critical belief, reject both stances and prefer the unbelieving cognitive styles instead.

One could also argue that 16-18-year-old teenagers in years 11-12 of secondary college, in the height of adolescence, are in a stage of resistance and even active rebellion against adults and thus also against the dominant religious patterns exhibited by adults. This might explain, at least in part, the downward trend we see in the ECSI graphs. Can we be reassured, however, that these teenagers and adolescents will return to the faith and engage themselves religiously again when in a later stage of their lives they graduate, look for a job, create a family, and settle into adulthood? Thus far, we are unaware of social research statistics that support this hypothesis. A more pessimistic interpretation could be that we are not just confronted here with a temporary developmental issue, but with a much deeper and definitive cultural shift away from a Christian religious world view.

In each of these hypotheses the question remains: how do we explain that even after 12 years of intense and purposeful Catholic religious education the Catholic faith seems to have lost so much of its plausibility and attractiveness for young people? This question is pertinent especially since the youngest students in primary school seem to start off with such an ardent, eager, and enthusiastic attitude. What can be done to halt and re-direct this massive shift from believing to unbelieving cognitive styles?

Let us examine the issue more closely. What is happening exactly in Catholic primary schools? If we look at the ECSI data on the factual level of the Victoria Scale (Figure 4), we see that primary school children perceive their school environment as a combination of monological (4.22) and dialogical (5.11) tendencies. Likewise, primary school teachers and leaders also perceive their schools as dialogical (5.25) but at the same time they do not strongly deny the presence of monological (3.63) pedagogical approaches. This is a first important key. 
Further, we see that both students and staff in Catholic primary schools deny that there are significant levels of religious and philosophical diversity present in the Catholic classroom. Although students and staff often have ethnically and culturally diverse backgrounds, still in most Catholic primary schools the presence and impact of real diversity on the curriculum content and pedagogical approach remains minimal. This is a second important key.

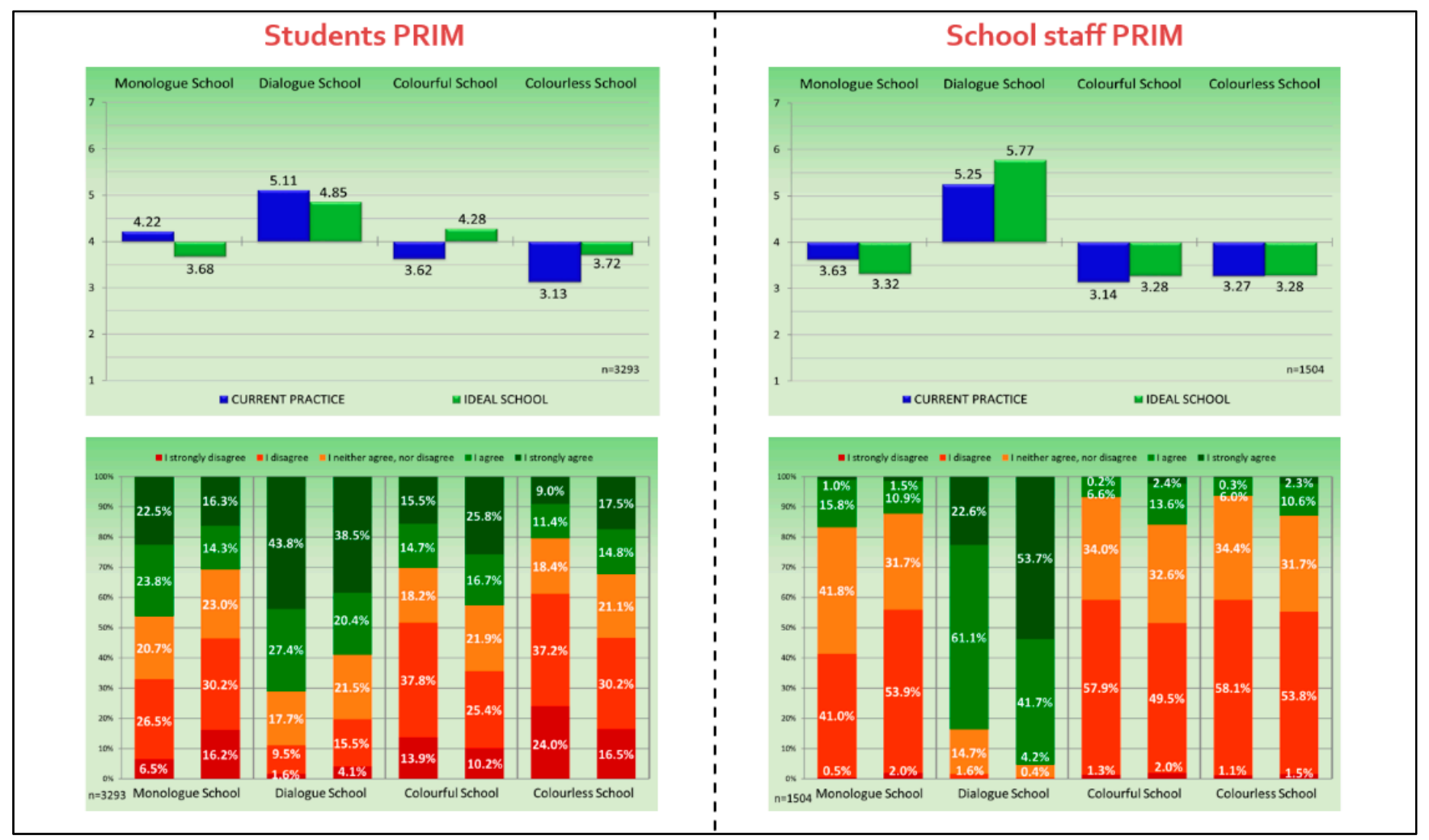

Figure 4. Victoria Scale results among students and staff in primary schools.

Technically, we describe Catholic schools that exhibit the above pattern as 'kerygmatic dialogue schools'. Dialogue is present but it is used in the first place as a means to introduce and to proclaim the Catholic faith to a large number of students. This school type prefers that the dialogue is not 'disturbed' by too much diversity coming from the social context. Primary schools are purposefully shaped as environments that are 'as Catholic as possible' in every conceivable way, which ultimately implies that 'non-Catholic' views and practices actually would not belong there. Such schools can be described as 'safe Catholic havens' amid a complex plural context. The identity construction of the student is closely aligned with the Catholic faith. Such schools offer children and teenagers an ideal place to develop a basic trust and a strong personal (Catholic) identity. The model of the kerygmatic dialogue school is predominant in Catholic education in Australia as well as many other places in the world.

Figure 3 shows what happens when students progress from the primary to the secondary education level. Where people's vision of their 'ideal school' is concerned, the support for a monological approach sharply drops. This is particularly striking when we compare the students in years 5-6 (3.6) with the students in years 11-12 (2.4) (see Figure 5). We find here the same pattern as in the PCB-Scale: where the older students are concerned, the secular colourful school model takes over from both the monologue school and even the dialogue school, at the same rate at which their levels of relativism and external critique increase. The same pattern is also true for school staff (but to a lesser degree), whose 
support for a monological attitude drops from 3.32 in primary schools to 3.13 in secondary colleges.

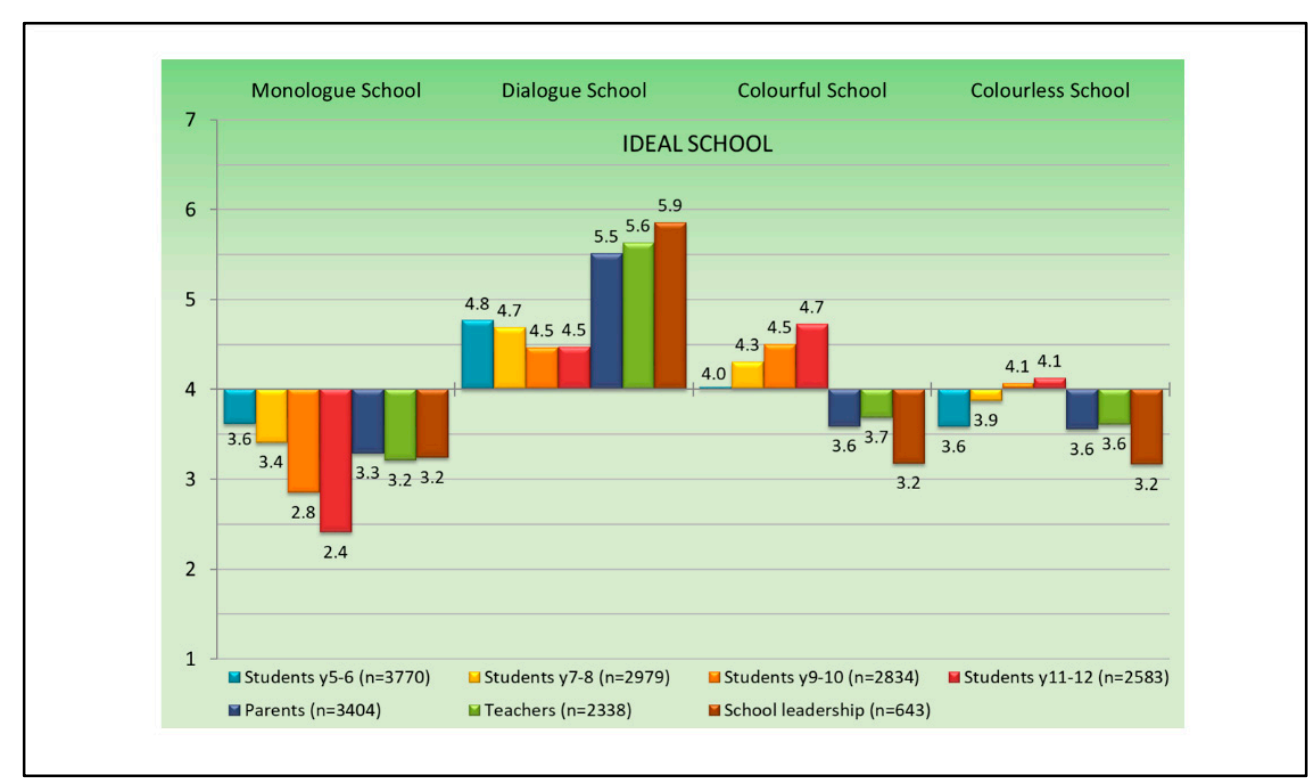

Figure 5. Victoria Scale results among all respondent groups.

In other words, the experience of the school as a 'safe Catholic haven' is interrupted when people leave the primary school and move into the very different environment of the secondary school. When children enter puberty and the effect of the catechesis of the initiation sacraments fades away, the impact of the kerygmatic religious education approach dissolves-like hot air that is released from an artificially inflated balloon.

The Melbourne Scale reveals the mechanism that is used to create such 'kerygmatic dialogue schools' (see Figure 6). Students in primary schools undergo a lot of Christian values education (5.05), which is intended to (re)confessionalise (4.70) the Catholic school and its members. The data indicate that educators make a very strong connection, almost a complete overlap, between the human experience and the Catholic answer to it. We have called this a 'mono-correlational' strategy. It assumes that the goal of religious education is to expose the one-to-one association between the values, virtues, experiences, and sensitivities of the students on the one hand, and the Catholic religious messages on the other. This approach tries to harmonise, synchronise, and reconcile the two, often by mediating the Christian message through so-called 'gospel values' that presumably are shared by everybody.

A kerygmatic type of dialogue school that habitually employs Christian values education is a harmonious context with little 'disturbance' from the outside, secular, and plural world. There are few real challenges, difficult questions, or unresolved issues. Everything fits nicely with everything else. Such a milieu easily produces literal belief in young children, as the data of the Post-Critical Belief Scale also show. Many primary school children feel safe in such an environment. When we examine the graphs, we see that there is little resistance to Christian values education (65.5\% approves). Primary school children are young and hardly aware of the significance of the diversity around them. Additionally, the primary school staff feel very comfortable in a values education setting ( $92.0 \%$ approves).

At the same time, though, the correlation or link between the values and the faith is less strong than one might be inclined to believe. On the normative level, reconfessionalisation drops (3.91) and secularisation grows (3.38), already among primary school children. This trend continues as the students progress into the secondary school level. For the majority of secondary school students, Christian values education no longer leads to reconfessionalisation (3.29) but goes hand in hand with a diminishing resistance to 
secularisation (3.80). Christian values education turns out to be counterproductive: the intention and the actual effect of this strategy are opposite.

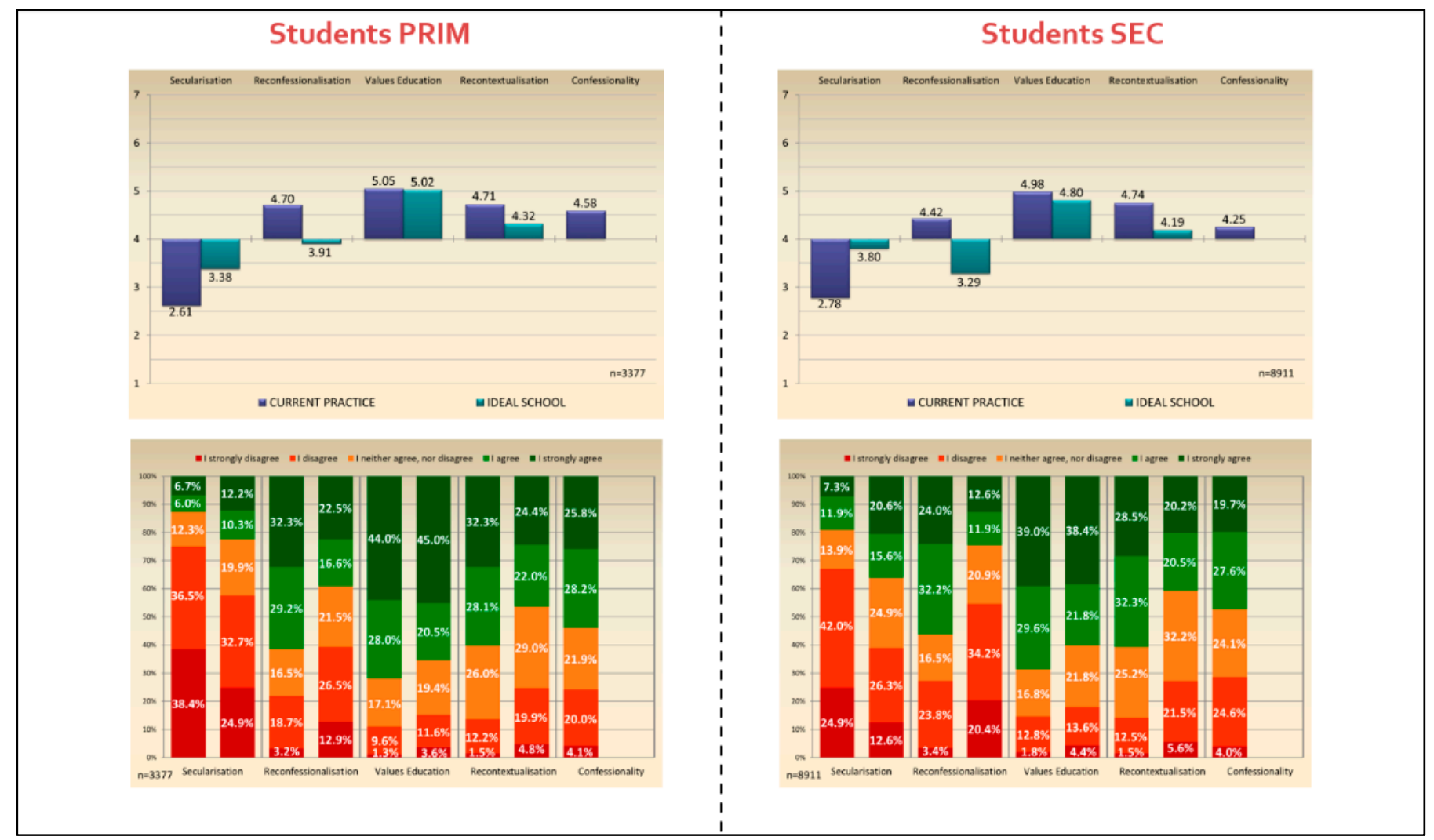

Figure 6. Melbourne Scale results among primary and secondary school students.

The 'kerygmatic balloon' of the Catholic primary gradually deflates, so to speak, in the course of secondary education. The monological use of 'dialogue' is interrupted by other voices. When teenagers and adolescents open up to the complexities of the world around them and accumulate real life experiences, the traditional and predictable mono-correlation of 'one' question with 'one' answer is broken. As mentioned in the description of the challenge, the result is not just the downfall of literal belief but also of post-critical belief and religious awareness in general. We detect consistent responses in the Victoria and the Melbourne Scale graphs. Not just the monologue school, but also the dialogue school is overruled and gradually replaced by the colourful school. Not just reconfessionalisation but also recontextualisation of Catholic identity is overruled and gradually replaced by the desire to secularise the identity of the school. Whilst they supported all forms of religiosityliteral and symbolic alike-during their time in primary school, most secondary college students have come to reject all forms of religiosity—literal and symbolic alike-when they approach graduation.

\section{Positive Theology and Psychology}

On several occasions I have had the privilege to visit Catholic schools in Australia. Invariably these are profound experiences. Teachers, principals, and parents create such a warm, harmonious, and welcoming environment where children and teenagers can grow and learn to respect and love each other, their families, their neighbourhoods, their country, and the world that God created. It is crucial that young people are given the opportunity to develop a sense of basic trust: trust in themselves, in the world, and, of course, in the Catholic faith. 'Gospel values' especially contribute well to developing strongly grounded and morally inspired personalities. In many Catholic primary schools in Australia, the 
desire to 'make Jesus real' in an all-encompassing and nurturing pedagogical context is so strong, that the 'golden dot' in the PCB-scale (Figure 1) often tends to shift through the line into the quadrant of literal belief.

Many educators intrinsically connect a 'positive theology' with an educational approach rooted in so-called 'positive psychology' that stresses individual and communal wellbeing. It concerns a humanistic movement that puts emphasis on happiness, positivity, bliss, and human prosperity for every student. Many Catholic educators are enthusiastic about maximising the 'eudaimonia' in an explicitly Catholic living and learning environment. To be sure, there is nothing wrong with fostering positive psychology in educational settings. It is commendable that schools-Catholic and otherwise-present themselves as positive educational environments that radiate safety, success, and self-assurance.

Nevertheless, there lies a risk in swiftly and easily harmonising 'happiness' with a certain moral and spiritual understanding of Christianity. It may appear that those things that hold the greatest value in life, the factors that contribute to a well-lived, fulfilling, and 'good life' go hand in hand or are even equated with the construction of a Christian way of life. Professionals in Catholic education, not only in Australia but all around the globe, are excited in a rather uncritical way about 'positive psychology' as a kind of highway to 'positive theology'. Kerygmatic dialogue schools create a safe, kind, happy, nurturing, open, and sharing community, with the questionable expectation that this is the way in which 'Christ' becomes 'real' for all involved-regardless of who they are and what their background or world view might be. Again, there are no issues with positive psychology as such, also not when it is correlated with positive theology. Issues arise, however, when they appear so closely related that they are identified as if they would be saying the same thing.

\subsection{An Exemplary Case}

In the summer of 2019, I visited a Catholic primary school in Australia and conducted a group interview with five students of year six (11-12 years old): Grace, Hannah, Erin, Nathan, and Joseph. It was on 5 August 2019, the morning in which the world media reported about a mass shooting incident in El Paso, Texas, USA that left twenty people dead. Here is a transcript of the interview (see Box 1).

Similar student interviews could be conducted in any Catholic school in Australia and elsewhere in the world. It illustrates all aspects of our analysis of the Catholic primary school pedagogy today, that are also confirmed in the ECSI research data.

The school is a 'safe haven' ("they are in America, we are in Australia"; "we are lucky with no shootings") based on Christian values education ("we are nice and open to each other", "we socialise with people") and clearly correlated with God ("we are really connected with God", "we like spending time with God"). Additionally, when confronted with evil—after hesitation-the students choose for positive psychology ("we try to keep positive"; "teachers don't put it in our minds") and positive theology ("we need to focus on what God is doing for us"). In the students' perception, positive psychology and positive theology go hand in hand. Evil itself is something that God allows ("something He might let slip sometimes"), arranges ("God has a plan"), or evil is even divine punishment ("God punishing us"). For these young students, it is almost unimaginable that God is angry or turns people away. Even if God had the right to be angry, the idea of a forgiving God is immediately introduced - at least for the person who genuinely repents. Thus, these young students are very well trained to behave in the framework of a joint venture between positive psychology and positive theology: both act like an identical twin. Each time the interviewer tries to introduce 'interruptions' in the harmonious representation of school life, the students try to adjust, reconcile, or remove them — even at the cost of a loving God.

Here we come across an example of mono-correlation between (positive) human experience and (positive) divine presence, connected to a literal understanding of how God deals with (evil in) the world. It is this mono-correlation that will ultimately be rejected by older students, as they increasingly discover that it is culturally and theologically implausible. Obviously, these teenagers owe their Catholic education a lot. It helped them 
to acquire a positive attitude towards life, a well-grounded basic trust, social competencies, and moral values and virtues. However, when they grow older and become young adults, it is as if they no longer need the religious framework that made all of this possible. When the 'balloon' deflates and the reality of life pours in, with all its complexity, multiplicity, ambiguity, difficulties, suffering, and pain, it is as if the Catholic faith no longer can be a relevant dialogue partner. Religious faith is something naive and sweet for children. Faith is like a 'launching platform' for life, but once the missile has left, the platform is no longer needed. Students graduate from Catholic education as well-educated, responsible, and reliable citizens, but they have left faith behind in (primary) school. The presupposition is mistaken that creating solid basic trust in young people using positive psychology, 'gospel values', and Christian virtues would automatically lead to the creation of convinced, robust, and resilient adult Catholic believers in the long term. It even appears to be counterproductive, as the ECSI data show. Now that we understand the situation in this way, then the question becomes how we can anticipate this process, and how we can come up with theological and pedagogical ways to prevent religious faith becoming irrelevant as students grow older?

Box 1. Group interview with 5 Australian students (11-12 years old).

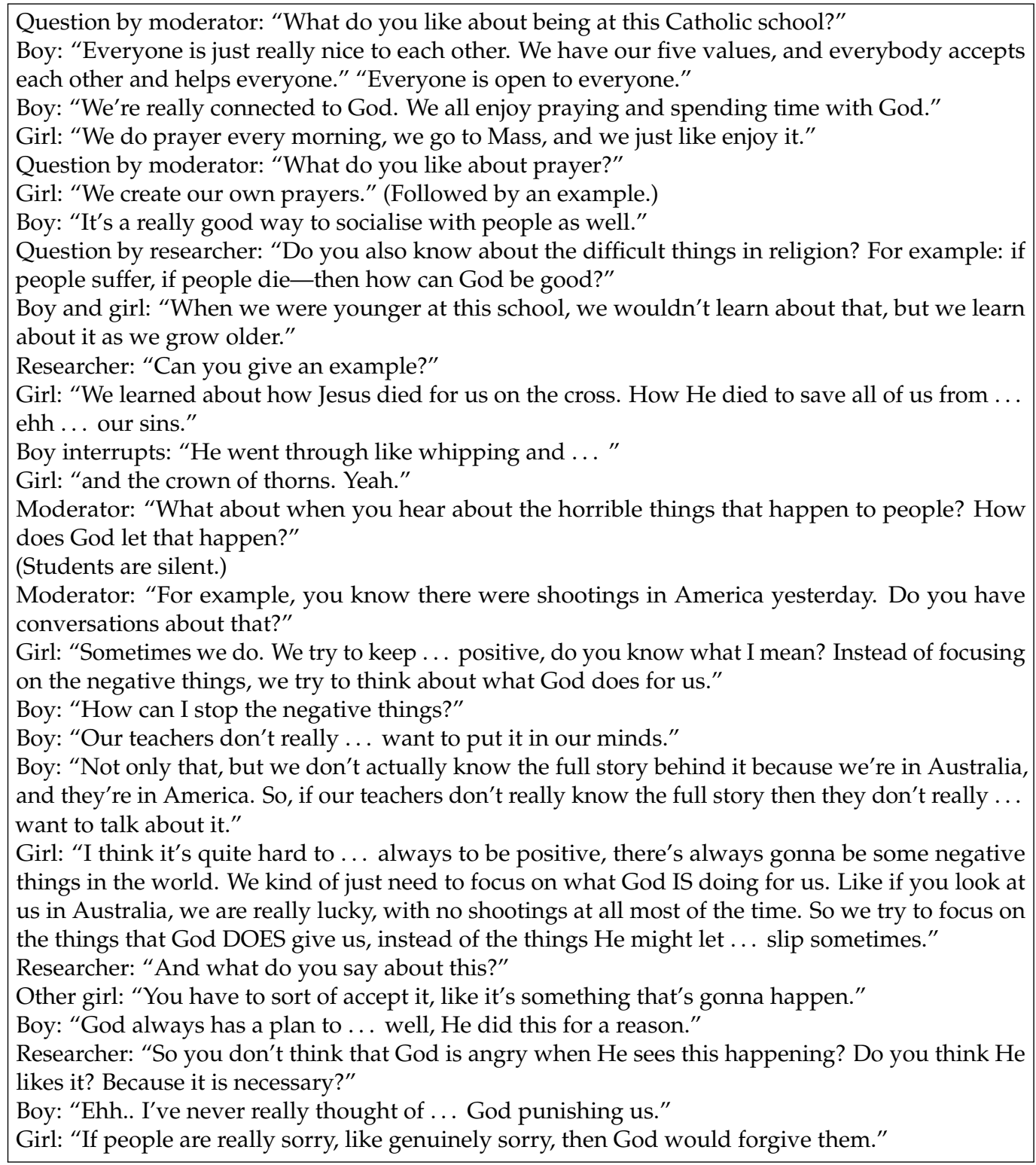




\subsection{Towards a New Perspective}

Let us try to pinpoint the profile of the students and staff in primary and secondary schools in Australia on the diagram of the РСB-scale (Figure 3). According to the ECSI data, many students in primary schools cross the line with literal belief. In the course of secondary education, however, this position drastically shifts: older students leave literal belief behind and transition fully into the quadrant of relativism. Where the teachers are concerned, they are close to the 'golden dot' or normative point according to ECSI, especially in primary schools. In secondary schools, we see how they also move more in the direction of relativism, together with their students but to a much lesser degree (see Figure 7).

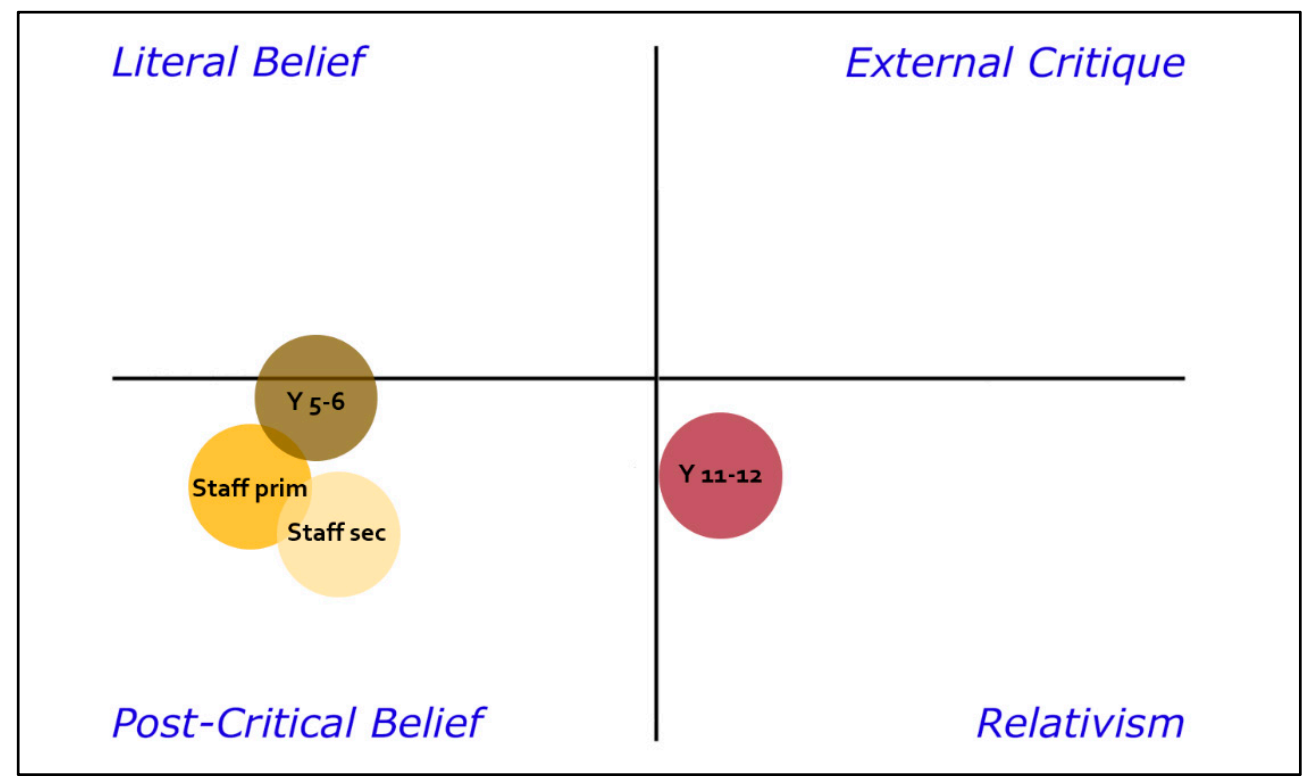

Figure 7. Position of students and staff in primary and secondary Catholic schools.

If this is the analysis of the current situation, then what alternative perspective could eventually change the usual practices in Catholic schools? In response to this analysis, we would like to explain and emphasise the reason for the exact position of the 'golden dot' on the PCB-scale diagram. The 'golden dot' represents the ideal belief stance on theological grounds. It is essential to understand why the golden dot deliberately does not touch the line that separates literal from post-critical belief. This denotes that post-critical belief always accepts the need for symbolic mediations to relate to the Divine Reality (Figure 1). It is important to be aware that our human condition imposes restrictions on the scope of 'positive theology'. No human being has ever seen God. We may desire to be with God, connected as closely as possible. Still, God always resists our temptations to 'frame' Him; God always escapes our attempts to 'capture' Him.

Although the little gap between the dot and the dividing line is narrow, it is extremely significant. From a pedagogical perspective, it implies a movement away from a correlational approach that attempts to capture God, towards an approach that seeks God more in the interruption of the existing order. It implies a movement away from a God who is immediately present and real, towards a God who remains ultimately hidden and needs to be found time and again. Our hypothesis is that Catholic schools in Australia are being based too strongly in positive theology. In order to prepare students better to become strong and resilient believers in the secular and diverse society of the future, Catholic schools need to compensate by integrating alternative theological views. In what follows, I will refer to these views as 'theologies of vulnerability and responsibility'. 


\section{Positive Theology and Theologies of Vulnerability and Responsibility}

What is the difference between 'positive theology' and 'theologies of vulnerability and responsibility'?

Put in simple terms, positive theologies consider God as certain, predictable, and knowable through the human experience, whereas theologies of vulnerability and responsibility consider God in terms of Otherness and even of Hiddenness and Absence. It is not the goal of this presentation to analyse this distinction in-depth but rather to show its pedagogical implications for Catholic school identity (Boeve 2007).

Positive theology confidently approaches the human experience as an encounter in which God is mediated, an experience that people can positively connect to and identify with. The 'golden dot' or the normative point in the PCB-scale as positioned in Figure 1 witnesses this possibility. We are compelled to try to connect to God and believe we actually succeed in doing so through the glimpses we receive of the Divine nature that is revealed in our human experiences, shaped by the Catholic faith tradition. Our human experiences invite us into a strong and vivid covenantal connection with the Divine Reality. Positive theologians assume they can actually point out how God is present and active in our lives. It is this positive experience that the students in the interview give witness to when they talk about the prayer practices in their school, about the openness, solidarity, and support they receive, and the forgiveness that is granted to people who erred. The 'golden dot' in Figure 1 deliberately does not touch the dividing line with literal belief, because despite our desire to get as close to God as possible, our experiences nonetheless always fall short of actually grasping the Divine. The kind of positive theology that refutes this limitation and assumes that 'true believers' actually have (or receive) this capacity breaks through the dividing line and ends up in literal belief.

Theologians who stress the importance of vulnerability and responsibility focus not so much on getting closer to the 'real' encounter with God. Rather, they are acutely aware of the gap between the 'golden dot' $^{\prime}$ and the dividing line with literal belief. Theologies of vulnerability and responsibility stress that God remains hidden from direct human experience. Human beings primarily can only meet the Other through their encounter with the human other (responsibility), or by being confronted with the 'un-experience' of God (vulnerability).

In a theology of responsibility, God reveals Godself as the Other in the other. God comes from elsewhere and interrupts our human existence. The Jewish philosopher Emmanuel Levinas speaks about a God who reveals Godself in the face of the vulnerable other (Pollefeyt 2018). The 'face of the other' does not refer to the physical appearance of somebody's facial features. Rather, it refers to the Otherness of the other, the specificity and vulnerability of the other as a human person. The other is the child who cannot go to school, the parent who cannot pay the school bills, the family who loses a loved one, the grandparent who stumbles at the school gate, the recently immigrated Muslim parent who does not master the English language, the fellow staff member who suffers from burn-out, et cetera. Such an encounter with the Divine in the Otherness of the other is not always pleasant and positive. On the contrary, this Divine encounter can turn our whole life upside down and demands a response in the form of 'responsibility'. The experience of 'alterity' or 'heteronomy' questions the orientation of my life towards 'me', 'myself', and 'my religion'. This experience compels me 'in God's name' to take up responsibility for the whole world. The Leuven theologian Roger Burggraeve claims it is 'time for another God' (Burggraeve et al. 2015). Especially young people in secondary colleges can be very keen towards a God who interrupts the status quo and demands truth, justice, and reconciliation. This becomes clear in their concern for poverty and social inequality, their protest against racism and discrimination, their commitment to combating climate change and safeguarding the future of the planet. With regard to a theology of responsibility, we can refer to the prophetic traditions in the Bible. Prophets are 'called' by God, often against their own natural inclinations, personality, or aspirations. They are not afraid even to stand up against 
ruling powers or religious systems. They even dare to question God 'in God's name', if necessary.

A theology of responsibility is closely related to a theology of vulnerability. They both refer to religious experiences where people start looking for God in times and places where things seem desperate and 'godforsaken'. Alas, there are many instances where people are lonely, disappointed, frustrated, suffering, enduring hardship, filled with doubt, stripped of hope, or confronted with death. In these negative moments, people feel an astringent desire for fullness of life and divine redemption-but they just cannot see or experience it. It is as if, in that crucial moment in their lives, God has been 'eclipsed'. No doubt, even young people are not spared these experiences, for example when they are confronted with the divorce of their parents, the death of a beloved grandparent, chronic illness, or the destruction of nature by bushfires.

However, also here-and especially here, the Catholic faith tradition has so much to offer. Medieval Christian mystics, for example, offer strong testimony of the search for God in the 'dark night'. They lost their sense of self and were unable to express what the experience was, other than by using metaphors of desire, pain, and darkness. Their religious language, stories, rituals, and symbols express a God of Otherness and give rise to liminal experiences of not-knowing, interruption, and paradoxes. Negative experiences happen unexpectedly, disturb existing narratives, human constructions, and presumed certainties. In religious language and symbolism, instead of revealing Godself, God rather hides Godself from us. God seems to escape from any attempt to define God with words, references, and symbols.

In a theology of vulnerability, religion is not put aside or rejected when times are dark. On the contrary, religious language is used to express negative experiences. In the Bible, the Psalms especially contain countless strong expressions of the theology of vulnerability. Many other examples can be given: the prohibition to make images of God (Exodus 4,6), the grieving of the prophets about the destruction of Jerusalem (Book of Lamentations), Jesus' agony in the Garden of Gethsemane (Luke 22,43-44), Jesus on the cross crying out to God (Matthew 27,46), or Paul's statement that "for now we see in a mirror, dimly, but then we will see face to face" (1 Cor. 13,12) (NRSV 1989).

In Catholic thought, positive theology and theologies of responsibility and vulnerability do not exclude each other. Countless examples can be given of how the Catholic faith tradition acknowledges both dimensions. Many people might know the opening words of the influential Vatican II document Gaudium et Spes ('the joys and the hopes (of the men of this age)') but most are unfamiliar with the words that directly follow: Luctus et Angor ('the griefs and anxieties'). Positive theology and theologies of responsibility and vulnerability are different dimensions of religious experience. We encounter both tendencies in different moments of religious life. Both theologies can in fact operate as mutual correctives to each other, while there also always remains a tension between them. This is clear even in the crucial event of the Incarnation, for example. In the incarnation of Christ, the infinite appears in the finite; the Divine is shown in a particular human being. At the same time, the infinite is not constrained by the finite; Christ is not only fully human but also remains fully God.

If we apply this distinction to religious education and Catholic school identity, positive theology believes that God can be 'captured' in correlations between the human experience and the Divine. According to theologies of vulnerability and responsibility, however, God always withdraws from our correlations that are inevitably too simple, superficial, and inaccurate. Precisely through these 'un-experiences' God reveals Godself to us as Someone who is 'other' and 'greater' than our human experiences. In positive theology, God is experienced as intimacy and connectedness, in a natural way continuously present and active in life, due to the mediation of signs, symbols, and relationships. In theologies of vulnerability and responsibility, however, the Transcendent is apprehended as beyond knowing, even in our signs, symbols, and relationships. God is a supernatural Mystery and absolute Other who only reveals Godself unexpectedly as a call for change, as an 
interruption, as emptiness or loss, or sometimes as darkness or confusion. In positive theology, God is encountered in a continual experience of meaning over time. In theologies of vulnerability and responsibility, however, God always surprises us in unpredictable, profound, and ecstatic events that are beyond human understanding. God is somehow 'experienced' and 'related to' in silence and loneliness, in doubt and not-knowing, in tragedy and natural or human catastrophes, in resistance against evil and the struggle to obtain justice, in martyrdom, conflict, and war.

In religious education and Catholic school identity there cannot be a preference for either positive theology or theologies of vulnerability and responsibility. It is not a question of either/or. Instead, Figure 8 indicates that there is a continuum between positive theology and theologies of vulnerability and responsibility, that exist in a tense relationship to each other.

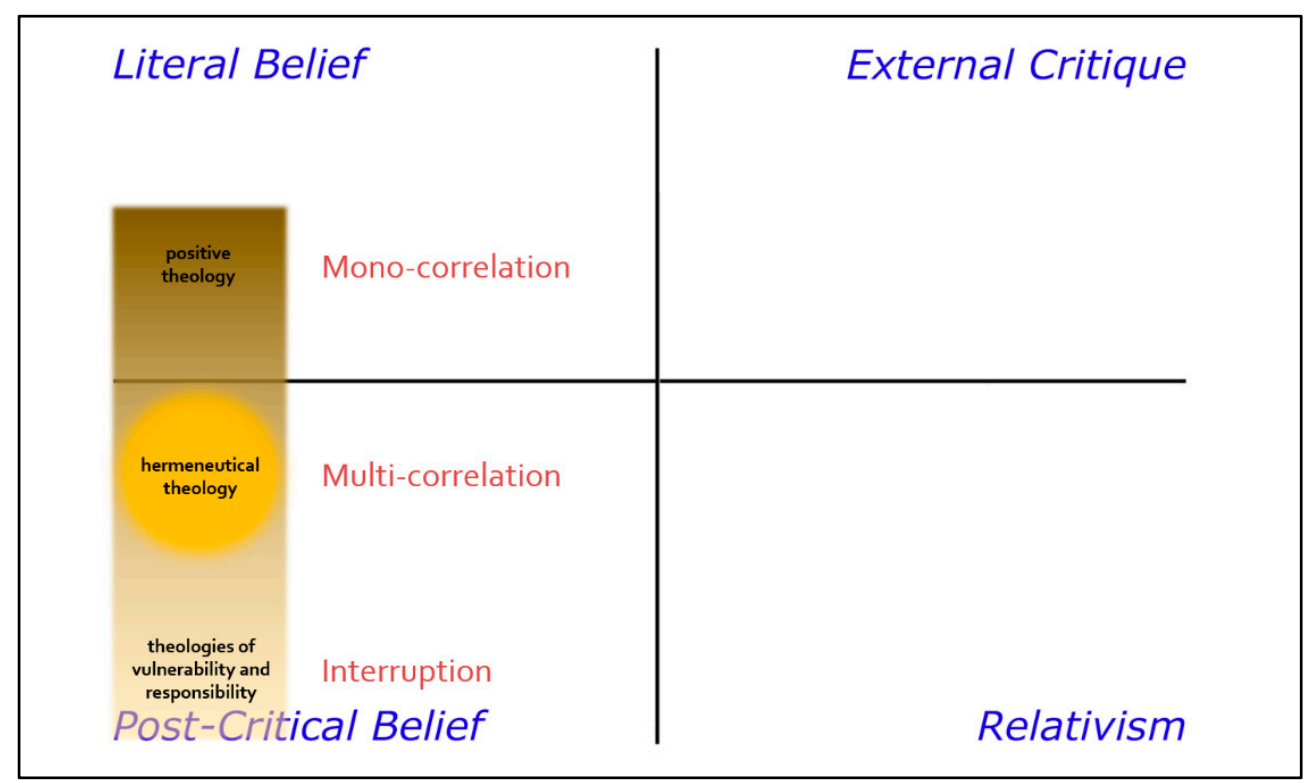

Figure 8. A continuum between positive and negative theology.

We suggest that this worthwhile and fertile tension is an invitation for leaders, teachers, and students in primary and secondary Catholic schools to engage with positive theology as well as theologies of vulnerability and responsibility. We hypothesise that this will transform students into steadfast believers who will not so easily ignore or reject their post-critical religious belief at those perilous times when literal belief fails, and convenient mono-correlations break their promise. We expect that the Catholic faith tradition will remain for them a dialogue partner for life, even when life reveals itself as more complex, vulnerable, mysterious, painful, and less 'happy'. In Catholic schools today, we need more 'Good Friday' and less 'Easter'. Where the Kingdom of God is concerned, we need to stress the 'not yet' rather than claiming too quickly the 'already'. The challenge for Catholic schools today is not that God would not be 'Emmanuel' (which implies 'God among us', correlated and incarnated), but on the contrary that too many things are too quickly, too easily, superficially, and even falsely identified as 'Emmanuel'.

The proposed transition to a Catholic school identity and religious education at school that includes a heightened awareness of theologies of vulnerability and responsibility implies a shift from a belief based only on answers and certainty, to a belief that can also deal with questions and the search for truth. It implies a shift from a belief based only on knowing, to a belief that can accept not-knowing and is open-ended. It is a shift from only finding answers and solutions in faith, to also probing the mysteries of life with the Bible as a guide. It is a shift from only experiencing 'happiness' in religious belief, to learning also to deal religiously with imperfection and pain. It is a shift from a presumed harmonious religious life, to an existence marked by ambiguities, paradoxes, and new vocations. It 
is a shift from using the Catholic faith as the culmination point of a formation process where all the pieces of the puzzle fall together, to a perspective that keeps the Christian narrative open.

As shown in Figure 8 of the PCB-scale, we identify with a hermeneutical theology that assumes a middle position between a theology that is exclusively positive on the one hand and theologies that exclusively refer to vulnerability and responsibility on the other. The 'golden dot' is positioned between a mono-correlational approach that assumes having answers, and an approach that stresses interruption, puts into question easy answers, and shows that God in fact escapes us. ECSI's normative position is the hermeneutical middle ground under the dividing line that distinguishes symbolic from literal belief, based on a rich multi-correlational approach of the tradition. This is a position that allows formulating faith-filled answers to human questions, while at the same time always holding on to the awareness that there are many aspects, perspectives, and possibilities that are not included in my answer-each of which in turn could be enriched or sometimes challenged by yet again other religious points of view, particularly in the encounter with others. By positioning the 'golden dot' below the dividing line with literal belief, we hope to invite education leaders and teachers to live and work in the tension between positive theology and theologies of vulnerability and responsibility.

The hermeneutical-communicative model (HCM) is a pedagogical approach for religious education in the classroom that provides students with the attitudes and skills needed to deal with such complex multi-correlation. A key aspect of the HCM method is to teach students to deal effectively with multiple interpretations, so-called 'hermeneutical intersections'. The HCM approach is hermeneutical because it insists on an openness for a multitude of possible interpretations. The Catholic approach is always presented as the privileged perspective, but with an awareness that other perspectives are possible and present in the classroom. A pedagogical approach that imposes just one interpretation on the students by means of mono-correlation is for that reason not hermeneutical. This remains true even when the imposed interpretation itself is the result of a hermeneutical activity. Although mono-correlation is most often used to spread literal readings of Bible texts, religious narratives, events, and experiences, it can also be used to impose specific figurative, metaphorical, and symbolic interpretations. The HCM method, on the contrary, is designed to keep the narrative open without reducing the complexity of human meaning-making. It invites the students to become interpreters themselves as they attempt to grapple with multi-layered religious topics, thereby multi-correlating those topics with the equally multi-layered contexts of their lives.

\section{Mapping the Spirituality of Teachers}

In March 2019, Dr. Rina Madden successfully concluded her PhD research at the University of Divinity in Melbourne. I had the privilege of being the promotor of this doctoral research project, in which Dr. Madden analysed the spirituality of primary school teachers in Australia (Madden 2018). To do this, she constructed a framework based on two dimensions. The first dimension (the horizontal axis) maps how the teachers relate to faith in terms of activity versus passivity. The second dimension (the vertical axis) is concerned with how the teachers experience the Transcendent Reality in terms of intimacy versus otherness, which refers to positive theology versus theologies of vulnerability and responsibility. This results in a typology with four quadrants, not unlike the PCB-scale (Figure 9). Dr. Madden conducted a series of interviews with primary school teachers and with their students as well. The responses were mapped on a new spirituality framework.

The analysis of the research findings shows that the majority of the respondents first and foremost relate themselves to positive theology (see Figure 9). This emphasis is evident across all the data pertaining to teacher spirituality and student spirituality, and also becomes clear from the description of religious education lessons. Teachers and students are very 'fluent' in the language of positive theology but feel much less comfortable with the language of theologies of vulnerability and responsibility. 


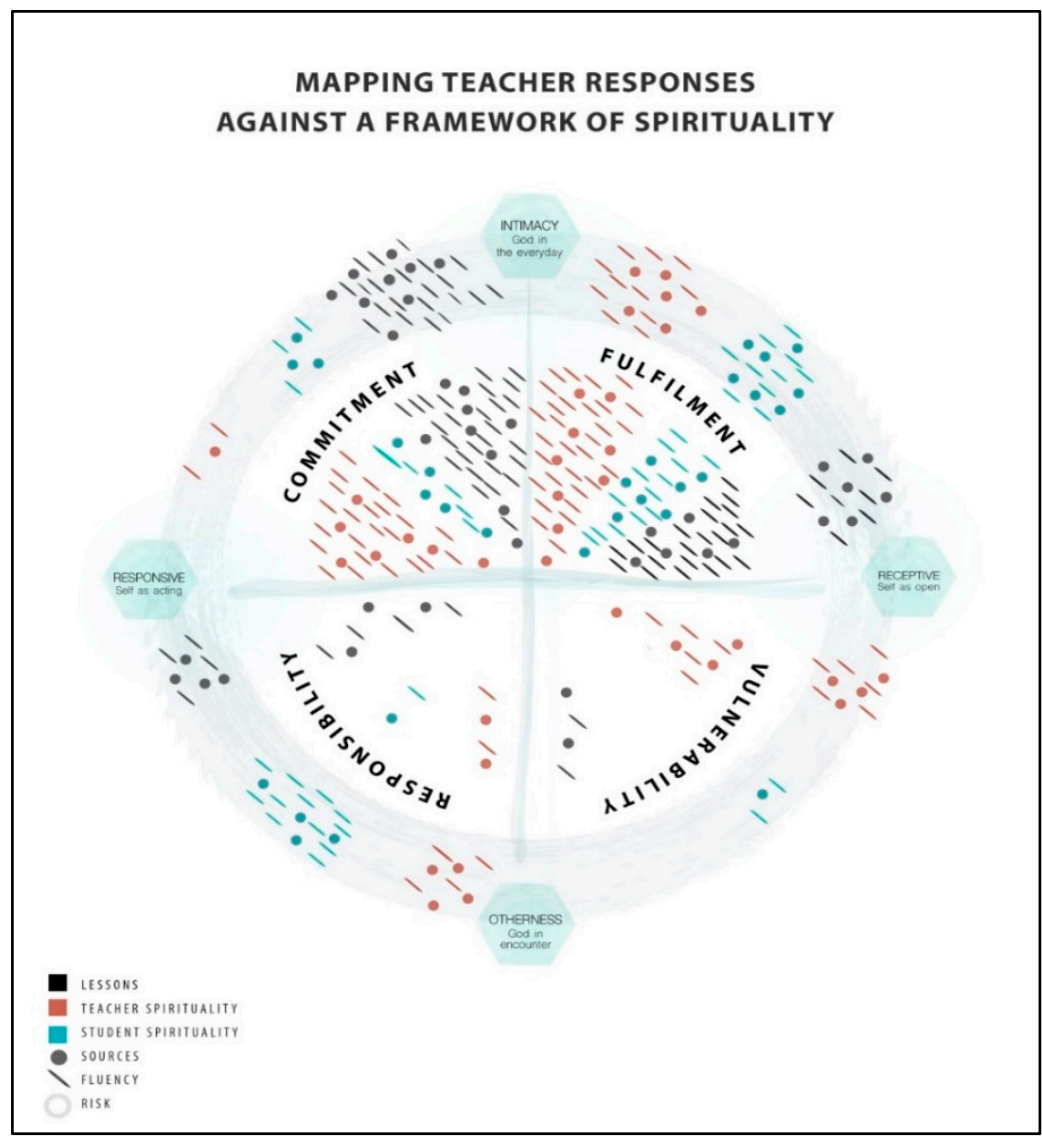

Figure 9. Dr. Madden's spirituality framework.

This finding is in line with the interview of the primary school students that we analysed above, and together these show the accessibility of a relational God in primary school. God is presented as intimate, loving, and affirming, and strongly aligned with themes of wellbeing and positive psychology. This approach fits well in a society that stresses support, cooperation, and self-affirmation. Rina Madden concludes: "The themes of forgiveness and reconciliation, cooperation and sharing, of finding satisfaction and peace through appreciating the beauty of the natural environment and in relationships with others are also neat and useful connections between an understanding of spirituality and wellbeing, made by teachers in their religious education lessons" (p. 237).

As they transition to the secondary education level, we see that young people no longer need God to attain their goals. Gradually, secular positive pedagogy and psychology take over. When these approaches clash with the contrariness of life and ultimately fail, the majority of the students do not return to the Christian religion to find a perspective they lack. After all, for many, the religion of their childhood was often never more than a temporary duplication of the positive pedagogy and psychology that it helped to establish. If only the students had experienced what happens when the contrariness of life is met with the radicality evoked by the Gospel, then the Catholic faith might have proved its relevance for their lives, both psychologically and spiritually.

\section{Ten Concrete Proposals}

What could be done to strengthen the understanding and the experience of theologies of vulnerability and responsibility in leaders and teachers in Catholic primary and secondary schools? How to establish a greater appreciation for the 'otherness' of the other and of the God of the Christian tradition, a God Who is sensitive until the end for the suffering, evil, and complexity of the human condition? How to equip teachers who can invite students-including the younger ones-to develop a resilient faith that is capable of 
grappling with the deep questions of God and the myriad sources of revelation? We finish this presentation with ten concrete proposals to realise this shift. The recommendations below are intended first and foremost for Catholic primary and secondary schools, but they have broader relevance as they also apply to the Catholic Church as a whole and to the way it manifests itself in other sectors worldwide.

\subsection{Create More Contact and Exchange between Leaders and Staff of Primary Schools with Leaders and Staff of Secondary Schools}

Religious education that suppresses the capacities of children risks becoming ineffective and counterproductive, in particular when the students experience more freedom, flexibility, and creativity in other school subjects. First of all, it is crucial never to treat children in terms of cognitive, moral, or religious deficiency. Do not consider children to be 'not yet' adults. Instead, they are unique beings with their own special characteristics, possibilities, and strengths. Childhood is not a deficient stage that should be overcome. Instead, it ought to be integrated as an integral part of the future identity of a person. This presupposes that adults believe in the extraordinary qualities and possibilities that children possess. Younger students are capable of much more than they are often given credit for. They can question, wonder, explore, and interpret, sometimes in a much more natural way than those who are older and supposedly 'wiser'.

Already at the primary level, educational standards in Australia support and expect these learning competencies in students. We refer here specifically to the 'General Capabilities in the Australian Curriculum', that include for example: critical and creative thinking; inquiring-identifying, exploring, and organising information and ideas; generating ideas, possibilities, and actions; reflecting on thinking and processes; analysing, synthesising, and evaluating reasoning and procedures; personal and social capability; self-awareness and self-management; understanding ethical concepts and issues; reasoning in decision making and actions; exploring values, rights, and responsibilities; interacting and empathising with others; and intercultural understanding (Australian Curriculum 2009). We suggest that the aspiration to build these capabilities, in recognition of the (religious) capacities that young people possess, fully applies in the field of religious education as well.

With all that in mind, it is important that primary school leaders and staff follow-up 'their' children as they transit to secondary school and carry on their educational careers. Likewise, it would be helpful for secondary school leaders and staff to be aware of the religious background of the teenagers they enrol. That way, primary and secondary schools coordinate their efforts to guide the faith journeys of the students who are entrusted to their care. After all, the challenge of religiously educating young people is a responsibility for primary and secondary schools alike. A common analysis and a collaborative approach would be most helpful, especially when primary and secondary schools often tend to be distinct entities that operate in different ways. In every teenager, adolescent, and adult, the child and the way he or she was introduced into faith is still present-even if faith is minimised or denied later in life ("I no longer believe in this or that"). Knowing the faith journeys of the students and understanding the actual effect on the longer term of the religious pedagogy used at school could be a crucial learning experience for every school leader and teacher.

A specific task, in this regard, is to create a common approach for children in years 5 and 6 (usually these are the final years of the primary school level) and teenagers in years 7 and 8 (the beginning of the secondary school level). This is an important period of transition, from a developmental and also from a religious perspective. A common approach in primary and secondary schools for this age group could help bridge the gap between primary and secondary schools concerning faith formation.

\subsection{Recognise the Signs and the Attitudes Associated with Socially Imposed Positive Theology}

Our research and school visits make clear how well students are accustomed to positive psychology and positive theology, and the strong bond between them. Students have a natural tendency to accommodate the wishes of the adults whom they trust and 
who have authority over them. They have been tutored and 'trained' to speak the religious language that is expected, and they conform to the religious behaviour that is taught by example (such as singing religious songs, reciting prayers, preparing for Mass, et cetera.). As is often said: no one is born a Catholic, one becomes a Catholic through initiation.

However, there is a thin line between initiation and indoctrination. Here are some criteria to distinguish between the two. To what degree is there respect for personal freedom of conscience and expression? To what degree does a school tolerate and invite creative thinking and critical questions? To what degree is there an openness for a diversity of responses and expressions?

Catholic schools today, notably those in Australia, are conscious of protecting the integrity of the human person, and of the vulnerable child in particular. Schools put a lot of effort in protecting the physical and psychological safety and wellbeing of all students, and this is very justified indeed. It is important to be aware that this concern also applies to the spiritual vulnerability of children. After all, we do observe how children are exposed to and expected to conform to a 'Catholic' perspective that is not genuinely theirs. For sure, in the coming decades, this concern will become an increasingly important topic in our pluralising and globalising world, where the impact of 'no religion' and 'external critique' will grow considerably. It is good to be prepared for this.

\subsection{Never Teach Students Religious Insights That You Do Not Believe Yourself}

A critical rule in religious education - that actually ought to be obvious-is never to teach something to children or teenagers that you do not believe yourself. Never teach something that you do not understand, that you disapprove of, or that lacks plausibility for you as an educator, wherever you stand. Teachers who are not personally initiated in the Catholic faith ought to refrain from teaching religion in a literal and mono-correlational way. The same is true, obviously, for teachers who are personally initiated, just because the $\mathrm{RE}$ curriculum (and sometimes also other curricula at school) requires them to teach it. In religious education classes, too many things are taught that need to be 'un-taught' later. Too much effort in religious education at school and in adult catechesis later in life is spent trying to undo the unfortunate views and perspectives that people acquired when they were younger.

All too often it happens that teachers, whose personal post-critical belief is poorly developed or who are not religious believers at all, feel 'unsafe' when asked to teach Catholic religious education. Paradoxically, it is often the relativistic and non-believing classroom teachers opt for the 'safest' option of introducing literal belief in students, contrary to their personal beliefs. They simply apply the 'mechanics' of mono-correlational Christian values education, embedded in the comfortable framework of positive psychology. In this way, the teachers do not need to invest their own personality, spirituality, and vulnerability in the teaching process. By teaching things they do not believe themselves-often encouraged by an RE curriculum with a reconfessionalising scope-the teachers install literal belief in young people that is not only misguided and unnecessary, but also counterproductive in the longer term.

\subsection{Learn How to 'Do Theology' with Children, and among School Staff}

In our book, Children's Voices. Children's Perspectives in Ethics, Theology and Religious Education, Annemie Dillen and myself argue for valuing the 'voices of children' as authentic sources for theology and children's theology as a new paradigm for religious education (Dillen and Pollefeyt 2009). As already mentioned, we need to leave behind the deficiency paradigm that considers children as 'not yet' adults with cognitive, moral, and religious limitations. It is unfair to evaluate children in the light of adult standards and adult faith. Instead, the theology of children has its very own standards. The way children believe in God is as authentic as the way adults believe. That includes the way in which children ask direct and 'naive' questions, sometimes make 'funny' arguments, pray in overly 'pious' ways, and come up with 'strange' insights. There is no need to be suspicious, afraid, or 
apologetic about their questions or hesitations, as if these were anticipations of disbelief. On the contrary, by allowing children to ask 'theological' questions, we allow them to prepare themselves to become resilient believers in the future.

In Catholic schools, doing theology with the students should also turn into doing theology with the whole school team. Teachers should not only be concerned with how to give religious formation to children and teenagers, but also how to receive faith themselves by theologising with them. In this sense, young people and their theological quests are a call of God to all of us.

\subsection{Develop Compliant as Well as Resistant Relationships with the Faith Tradition and the Divine}

Traditionally, Christians are used to identifying their religious belief with obedience, with giving up one's own will, ideas, and desires. Many Christians regard authentic belief as a compliant belief. A 'good Christian' submits himself/herself to God as a higher power, to God's commandments and laws, to dogma and Church teachings. In the Jewish faith tradition, we find another relationship with the Divine that has often been forgotten in the Christian faith tradition. I am referring to the Talmudic wrestling with the Divine, dialoguing, debating, and even contending with God. Many biblical figures testify of a vulnerable and resistant relationship with God: Abraham, who defends the righteous people in the city God wants to destroy; Job, who questions the justice of God in light of undeserved suffering; or Jesus' words on the cross: "My God, my God, why did you abandon me?" (Mt 27:46).

A particularly interesting biblical figure here is Jacob, who wrestles with the Angel throughout the night and receives at the end a new name (Gen. 32:23-32). Here is an eminent example of a theology of vulnerability in the First Testament. Jacob wrestles with a stranger until the breaking of the day, and finally asks his name. However, the stranger refuses to give his name. God remains a mystery. He asks Jacob to give his name. He blesses Jacob and changes his name to 'Israel', meaning, 'contends-with-God'; "for you have striven with God and with men, and have prevailed" (Gen. 32:29). When the sun comes up and the stranger leaves, Jacob walks away, limping. Even if the stranger was not defeated, it was Jacob who was the strongest. He won, although he left the battlefield limping. Jacob's audacity shows a resistant relationship with God that takes the risk to confront God with his promises in the name of His covenant. It is the confession of a God who likes children asking difficult questions, and who blesses the struggles that teenagers have with Him. Dealing with the Catholic faith tradition in a resisting way, indeed wrestling with it, is not a rejection of faith but it is building a relationship with the God who reveals Godself through that tradition.

\subsection{Positive and Also Vulnerable Life Experiences in the Light of Faith}

Life is not always a feast. The core of human life sometimes reveals itself in the most difficult moments. According to the Flemish psychiatrist Dirk De Wachter, the increasing numbers of burn-outs among young adolescents today is due to the fact that they have not learned how to be 'unhappy' (De Wachter 2019). He warns against the risks of too much positive psychology in primary education. "We make princes and princesses of all of them. We pamper them to the extreme and we confuse this with love. We cry out to them: 'You are capable of everything!'; 'You can do everything you like!'; 'As long as it is fun!'; 'As long as you become happy!'; 'You can do all the studies in the world!'; 'You can have all possible jobs!'. But, of course, this is completely untrue. This freedom is an illusion."

The problem arises when such positive psychology is unilaterally correlated with positive theology. Often, Catholic schools presume a kind of uncritical continuity between positive psychology and Catholic education, as if the highest good of the Catholic faith would be 'happiness' as defined in positive psychology. Catholic faith is reduced to a kind of 'full life insurance'. The price to pay is that the Catholic faith would be rejected at the inevitable moment when (religious) life cannot keep its promise. This is tragic irony, since the Christian message does not deliver a guarantee for a life filled with happiness, but 
becomes particularly relevant at moments of unhappiness, brokenness, sin, suffering, and death. Especially in tough times, Christianity shows its relevance and provides resilience in the life of the human person. Often such a faith becomes a 'limping' faith, indeed. It has gone through disappointment, loneliness, uncertainty, unanswered questions and desires, separation from God and human beings. These life experiences and negative emotions are also an integral part of the life of children and teenagers. Educators need to recognise this and work with it, and not only in Catholic religious education.

\subsection{Do Not Avoid the Difficult Aspects of Religion, Especially in the Bible}

Unfortunately, Bible didactics in Catholic schools are often completely embedded in positive theology. The Bible is presented to children and teenagers as one, consistent, perfect, moral message. The manifold difficult passages and principally the 'texts of terror' are conveniently skipped because they seem to undermine the harmonious ethical presentation of Biblical reality.

Later in life, though, the Bible as 'ethical recipe book' is closed and put aside. This happens when teenagers and adults stumble upon the incongruities and contradictions in the text. Or when they discover aspects in the text that do not fit within their preconceived notions of positive psychology, such as a God who has his enemies executed or who rejoices in the killing of great numbers of people. There are Bible passages in which God asks sacrifices, even of one's own children. There are texts that contain sayings attributed to Jesus that could be read as pro-death penalty, unfriendly for women, anti-Semitic, et cetera.

Therefore, there is a need for a different Bible didactics that allows more place for dia$\log u e$ with the text, with the original context of the author(s) in relation to the contemporary context of the reader(s). We need a Bible didactics that fosters also a resistant attitude next to a merely compliant reading. This presupposes that we see revelation happening not so much in the text itself, but between the text and the reader(s) (Pollefeyt and Bieringer 2005).

\subsection{Create a Dialogue between Science and Faith}

One of the risks of a mono-correlational pedagogy in (religious) education is that it introduces literal belief in students and, on a deeper level, that it installs in them a binary way of thinking. When literal belief becomes-unavoidably - untenable, it is nonetheless possible that the binary cognitive belief structure remains intact. It often happens that religion, as the overall system to give answers to life's questions, is replaced by science as an overall system to provide purpose and meaning. Literal belief is replaced by literal disbelief. Nonetheless, it remains literal. Authority is given only to what is scientifically known and proven. The mono-correlation remains intact, but the difference is that the correlation now happens with science instead of religion. The latter is rejected as un-scientific or even anti-scientific.

For that reason, a critical dialogue between science and faith is crucial, especially in secondary colleges (but starting already in primary school as an evidence). In such a dialogue, science is neither just a simple confirmation of the Christian story (literal belief), nor just a rejection of religion (external critique), but a partner in the search for a better understanding of human nature and the world we live in - even though science and faith speak a different language and the results of the search for meaning in science and religion belong to different discourses (Boeve 2006).

\subsection{Foster an Attitude of Inquiry and Dialogue Regarding Matters of Faith}

Inquiry-based learning is used to make students independent thinkers in all areas of education. This valuable pedagogical approach, that is employed in many Catholic schools in Australia, can also be fruitful for a multi-correlational learning of religion. Inquirybased learning encourages students to pose questions, to investigate, to think critically, to approach problems from multiple perspectives, and to draw conclusions about the meaning of religion for their personal lives. Students become active learners of the Catholic faith and come to own their learning processes, instead of being passively submitted to a 
pre-determined mono-correlation that is artificially forced upon them. Moreover, inquirybased learning also contains an invitation to discover and to experience a rich diversity of spiritualities that are present and active inside the Catholic faith tradition.

It is important that also the teachers are actively involved in this process of inquiry regarding the Catholic faith. This is hardly possible or even not allowed in a school context that is a mono-correlational Catholic haven. Sometimes, we see in Catholic schools signs of a taboo regarding critical questions, searching into the tradition, trying to find new answers to old questions, or regarding much-needed recontextualisations of old concepts, traditions, and rituals (e.g., evil, grace, resurrection, etc.). In turn, the taboo keeps the 'Catholic balloon' inflated and intact, while the school members—students and teachers alike-disconnect their professional behaviour from their private experiences of faith.

\subsection{Offer Teachers (in Training) Experiences from Both Positive Spiritualities and Spiritualities} Connected with Vulnerability and Responsibility

"Ultimately, we know God as unknown", St. Thomas Aquinas wrote in his work on the Trinity. More recently, Pope John Paul II wrote in Mulieris Dignitatem: "For biblical Revelation says that, while man's 'likeness' to God is true, the 'non-likeness' which separates the whole of creation from the Creator is still more essentially true" (Pope John Paul II 1988). Quotes like these warn us against theology becoming too positive and running the risk of misleading (young) people: too much unilaterally positive theology may give the impression that human reason and experience would be able to understand God completely and unequivocally. Such a theology would run the risk of assuming that it can make Jesus completely accessible to the degree that the mystery and the incomprehensibility of the Creator is dismissed. In that case, people confuse God with what is known about God. Theologies of vulnerability and responsibility are a necessary complement of positive theology when they underscore what God is not or what can not be known about God. This requires a spiritual attitude of modesty, discipline, austerity, and humility. In education, we need to have the courage to say more often and more clearly that certain things and situations "are not of God", that they "are not God's will".

When teenagers or adolescents admit that they "no longer believe in God", in many cases they in fact exercise critique on a too positive theology: they express who God is not for them. Such expressions are genuine theological statements that need to be taken seriously. Clarifying who God is not, can be as useful as trying to understand how God positively reveals Godself. Teenagers often reject a God who lacks cultural and personal plausibility. Perhaps this rejection creates the necessary space to discover God anew in another way? Can we accompany our students on this via negativa, joining them in their inquiries, struggles, and hesitations? Can we take the risk, together with our students, to encounter that 'other God' who reveals Godself as an immense depth, as Light in the shadow of vast unknowability? Perhaps this is the biggest challenge of all for religious education in our time: can students 'in' and 'beyond' theologies of vulnerability and responsibility discover anew that God who lives truly and who seeks us with limitless Love from the other side?

\section{Conclusions}

All over the world, Catholic schools are respected institutions that are renowned for the quality of the education they offer. They create an educational context, inspired by the Gospel of Jesus Christ, to prepare the next generations to become competent and responsible people in their private lives, and distinguished citizens in their societies. A good atmosphere, a positive anthropology, and a safe environment are preconditions to make the formation of young people possible. No doubt, a positive Gospel message can contribute to such a formation. It is not our intent to question the power and the success of these kinds of Catholic educational contexts. Parents rightfully expect from Catholic schools a focus on safety, quality, positivity, and faith. Catholic schools are, in the first place, outstanding educational environments. They accomplish the educational needs of their 
countries above and beyond expectations, including the formation of complex expertise and capacities in young people (Elshof 2019).

Notwithstanding these educational qualities, when we focus on the affiliation of contemporary students with the Catholic religion, our ECSI research data confront us with a remarkable decline that coincides with the students' age. Many primary school children go along with the Catholic religion at school but have left faith behind by the time they turn eighteen. In this contribution, we have tried to formulate a hypothesis that explains this trend, based on the analysis of the empirical data in one Australian diocese using ECSI's theological and educational paradigms. Our explanation is that, regarding religious formation, 'too much good is bad'. Many Catholic primary and secondary schools are prepossessed with positive psychology that they connect too closely with positive theology. Schools risk neglecting the development of certain religious capacities in young people, or even discouraging and eliminating these capacities through the continual use of 'mono-correlation'. The result is that, for the upcoming generation, religious faith fails to be a pertinent dialogue partner when life reveals its complexities and challenges.

For this reason, we suggest introducing in religious education in primary and secondary schools-alongside to positive theology-more interruptive experiences framed in theologies of vulnerability and responsibility. We propose shifting the focus of attention in religious education to a deeper and more complete understanding of religious human life, an understanding that also includes challenging experiences, such as: not-knowing, doubt, silence, mystery, struggle, resistance, estrangement, loss of meaning, tragedy, and brokenness-eminent places where people discover traces of God, mysteries that somehow reveal the Transcendent Reality. This coincides with an increased development of religious capabilities in line with the thrust of the 'General Capabilities in the Australian Curriculum' that apply to other school subjects as well (Australian Curriculum 2009). The hypothesis is that these adjustments would create more resilient believers whose faith is embedded deeper in their existence. When life becomes more complex and challenging, they would possess the skills to interpret that complexity in the light of Catholic faith.

Educators can take heart regarding the reactions of the parents of the students in Catholic schools. Mothers, fathers, and other family members might worry about the 'difficult topics' their children and teenagers are presented with in religious education, and their concerns are important for schools. However, there is no reason why schools should hesitate to present and explain to parents the same justification elaborated above. After all, if we examine the profile of the parents in our empirical data (see the dark blue bars in Figures 1 and 3), we see that a vast majority of the parents prefer for their children a dialogue school that prepares them to become resilient believers capable of relating to diverse views and practices. Often, parents no longer know themselves how to prepare their children for a world that is unsafe, also from a religious point of view. Parents are looking for an educational environment that balances between positive theology and theologies of responsibility and vulnerability. Catholic schools that focus on this balance will have a unique educational position and will revitalise the Catholic faith in our communities.

The remedy we propose does not prefer theologies of vulnerability and responsibility above or even against positive theology. Catholic religious education needs to find the right balance between both perspectives. From a Catholic point of view, the positive perspective is paramount, although never without interruption. Put in more theological terms: believers who fail to appropriately acknowledge the central meaning of, for example, forgiveness, the eucharistic presence of Christ, or the significance of Easter, would destroy the ultimate perspective to which Catholic faith is finally oriented. However, at the same time we must remember that there is no forgiveness without $\sin$, no eucharist without sacrifice, and no Easter without Good Friday. Believers who fail to appropriately acknowledge sin, sacrifice, or crucifixion move into perilous territory. Ignoring or suppressing the 'darker' aspects of human existence might cause them to fester subcutaneously, in people's lives as well as in the Church. "The mystery of suffering can only be met by the mystery of care"; not by avoiding the 'darkness' altogether (McAleese 8th president of Ireland, 2011). 
Actually I don't believe anything,

And I doubt everything, even You.

But sometimes, when I think that You live truly,

Then I think that You are Love, and lonely,

And that, with the same despair, You seek me,

As I seek You.

Gerard Reve, Closure of the Day (Reve 1966)

Funding: This research received no external funding.

Institutional Review Board Statement: The study was conducted according to the guidelines of the Declaration of Helsinki, and approved by CECV ECSI Steering Committee (https:/ / www.ecsi.site/ au/partners/) and LRD KU Leuven (service Agreement, 22 November 2019).

Informed Consent Statement: Informed consent was obtained from all subjects involved in the study.

Data Availability Statement: All datasets are available. Please contact the author by email: didier.pollefeyt@kuleuven.be.

Conflicts of Interest: The author declares no conflict of interest.

\section{References}

Australian Curriculum. 2009. General Capabilities. Available online: https://www.australiancurriculum.edu.au/f-10-curriculum/ general-capabilities/ (accessed on 3 March 2020).

Boeve, Lieven. 2006. God Onderbreekt de Geschiedenis. Theologie in Tijden van Ommekeer. Kapellen: Uitgeverij Pelckmans, pp. $128-51$.

Boeve, Lieven. 2007. God Interrupts History. Theology in a Time of Upheaval. New York: Continuum.

Burggraeve, Roger, Guido Caerts, and Paula Veestraeten. 2015. Hoog Tijd voor een Andere God. Bijbels Diepgronden Naar de Ziel van ons Mens-Zijn. Leuven: Davidfonds.

Congregation for Catholic Education. 1997. The Catholic School on the Threshold of the Third Millennium. Vatican City: Liberia Editrice Vaticana.

De Wachter, Dirk. 2019. De Kunst van het Ongelukkig Zijn. Tielt: Lannoo.

Dillen, Annemie, and Didier Pollefeyt, eds. 2009. Children's Voices. Children's Perspectives in Ethics, Theology and Religious Education. Leuven: Peeters.

Elshof, Toke. 2019. Primary School Parent's Perspectives on Religious Education. Edited by Michael T. Buchanan and Mario M. Gellel. Singapore: Springer, pp. 113-24.

Madden, Rina. 2018. The Hermeneutical-Communicative Model at Work in the Primary Classroom: Empirical and Theological Research. Ph.D. Dissertation, Australian Catholic University, Melbourne, Australia.

Pollefeyt, Didier, and Reimund Bieringer. 2005. The Role of Biblical and Religious Education Reconsidered. Risks and Challenges in Teaching the Bible. In Normativity of the Future. Reading Biblical and Other Authoritative Texts in an Eschatological Perspective. Edited by Reimund Bieringer and Mary Elsbernd. Leuven-Paris-Walpole: Peeters, pp. 377-402.

Pollefeyt, Didier. 2018. Ethics and Theology after the Holocaust. Leuven: Peeters, pp. 109-26.

Pope John Paul II. 1988. Apostolic Letter Mulieris dignitatem. On the Dignity and Vocation of Women on the Occasion of the Marian Year. Rome: Libreria Editrice Vaticana.

Reve, Gerard. 1966. Nader tot U. Amsterdam: Van Oorschot. 